\title{
Behavioral factors of cardiovascular risk in medical doctors of different specialties
}

\author{
Isayeva Anna*, Vovchenko Maryna, Rieznik Larysa and Isakova Elizaveta \\ Government Institution "National Institute of Therapy named by L.T. Malaya of National Ukrainian Academy of Medical Science", Kharkov, Ukraine
}

\section{Introduction}

Correction of the main behavior risk factors (smoking, unhealthy eating, low physical activity, excessive alcohol intake) can reduce morbidity and mortality from chronic non-communicable diseases [1]. The basis for behavior changes is individualizing counselling. The European Guidelines on cardiovascular disease prevention recommends ten "steps" to facilitate behavior changes. It was recommended by the Experts:

- to develop a therapeutic alliance; to counsel all individuals at risk of or with manifest cardiovascular disease;

- to assist individuals to understand the relationship between their behavior and health;

- to help individuals assess the barriers to behavior change;

- to gain commitments from individuals to own their behavior change;

- to involve individuals in identifying and selecting the risk factors to change;

- to use a combination of strategies including reinforcement of the individual's capacity for change;

- to design a life style modification plan; to involve other healthcare staff whenever possible; to monitor progress through follow-up contact [2].

Despite the fact that the team for primary prevention of chronic non-communicable diseases includes, as a rule, nurses, dietitians, physical activity instructors, the central figure whose opinion determines the decision taking by patients is a medical doctor. In this case, doctor's compliance with healthy lifestyle principles is rather important. If a doctor himself/herself keeps up a regular training program, follows the healthy nutrition principles, and does not smoke, he/she would be more likely to predispose the patient in a similar way. Besides, a medical doctor's profession is associated with high level of chronic stress. This is an independent risk factor, and compliance with healthy lifestyle is extremely important for doctors themselves.

The purpose of this study was to investigate the behavioral risk factors in medical doctors of different specialties.

\section{Materials and methods}

Fiftyone doctors of four different specialties were examined - cardiologists - 14 (27.5\%), pulmonologists - 9 (17.6\%), gastroenterologists $-12(23.5 \%)$ and therapists - 16 (31.4\%). Majority of study subjects were women -27 individuals $(62.7 \%)$. The number of male subjects was 24 individuals, respectively (47\%).
Seventeen doctors in the examined cohort (33.3\%) had hypertension; 8 (5.9\%) had confirmed chronic coronary heart disease, 2 doctors (3.9\%) suffered from bronchial asthma, 11 (921.6\%) had established obesity, $3(5 \%)$ had diabetes mellitus type 2, and $2(3.9 \%)$ had the established diagnosis of chronic gastritis.

All examined doctors underwent height, body mass, and waist circumference measurements. Body mass index (BMI) was calculated using the formula: mass $(\mathrm{kg}) /$ height $\left(\mathrm{m}^{2}\right)$. Physical activity was assessed by the number of steps walked within a day using a pedometer Omron Walking style III step counter HJ-203-EK. The examined subjects measured the number of steps walked within 3 days, after which the mean number of steps a day was calculated.

Body composition was measured using bioelectric impedance method on an apparatus Omron Body Composition Monitor BF511. The ratio of muscular and fatty tissue, as well as visceral fat index, were assessed.

Evaluation of nutritional habits was performed using a questionnaire. Table 1 shows the questions used for revelation of doctors' nutritional habits.

Statistical analysis was performed with SPSS software, version

\section{Results}

The median subjects' age was $48.0[32.5 \div 55.0]$ years old. Table 2 shows anthropometric parameters registered at doctors' examination.

Body mass index in doctors of different specialties conformed either to excessive body weight or to obesity of different degree. Thus, median BMI in cardiologists was $29.9 \mathrm{~kg} / \mathrm{m}^{2}$, the same in therapists was $30.1 \mathrm{~kg} / \mathrm{m}^{2}, 30.0 \mathrm{~kg} / \mathrm{m}^{2}$ in gastroenterologists and $29.2 \mathrm{~kg} / \mathrm{m}^{2}$ in pulmonologists. Figure 1 shows the ratio of fatty and muscular tissue mass in doctors of different specialties.

Only 4 (7.8\%) of the examined doctors smoked, and 5 (9.8\%) had a smoking history, more than 5 years ago.

Results of calculation of the number of steps walked within a day are indicative of insufficient physical activity of the majority of study subjects (Table 3 ). Thus, the median number of steps walked within a

Correspondence to: Anna Isayeva, $\mathrm{MD}, \mathrm{PhD}$, Head of the Department of Chronic Non-Communicable Disease Prevention, The Government Institution, National Institute of Therapy named by L.T. Malaya of National Ukrainian Academy of Medical Science, Kharkov, Ukraine, Tel: +380504006550; Fax: +380577701538; E-mail: anna_isayeva_74@yahoo.co.uk

Received: July 14, 2017; Accepted: July 31, 2017; Published: August 06, 2017 


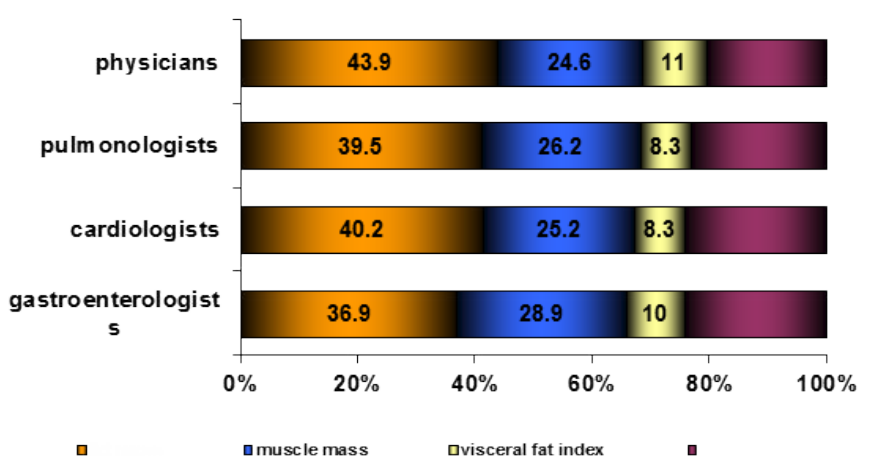

Figure 1. The ratio of fatty and muscular mass and visceral fat index in doctors of different specialties.

Table 1. Assessment of nutritional habits in the examined doctors' cohort.

Do you consume more than $5 \mathrm{~g}$ of sodium chloride a day?

Are you aware of the necessity to limit the salt consumption?

Do you exclude trans fats from the diet?

Are you aware of possible negative effects of trans fats on the health?

Do you examine the composition of food products when you buy them at a supermarket? Do you deem necessary knowing the composition of food products before their consumption?

Table 2. Anthropometric parameters of examined doctors.

\begin{tabular}{|l|l|l|}
\hline Variable & Males $(\mathrm{n}=24)$ & Females $(\mathrm{n}=27)$ \\
\hline Weight, $\mathrm{kg}$ & $71.5[62.0 \div 85.5]$ & $69.0[58.5 \div 90.5]$ \\
\hline Height, $\mathrm{cm}$ & $175.0[173.0 \div 178.5]$ & $164.05[158.0 \div 168.0]$ \\
\hline Body mass index, $\mathrm{kg} / \mathrm{m}^{2}$ & $25.5[22.0 \div 32.3]$ & $26.9[24.0 \div 35.5]$ \\
\hline Waist circumference, $\mathrm{cm}$ & $89.0[86.0 \div 92.0]$ & $82.0[75.0 \div 93.0]$ \\
\hline Fatty tissue, \% & $39.6[33.5 \div 48.4]$ & $38.1[31.6 \div 42.0]$ \\
\hline Visceral fat, \% & $8.5[6.0 \div 12.5]$ & $12.0[8.5 \div 19.5]$ \\
\hline Muscular tissue, \% & $27.1[24.50 \div 31.0]$ & $26.5[23.0 \div 30.05]$ \\
\hline
\end{tabular}

Table 3. Number of steps $(\mathrm{Me}[25 \% \div 75 \%])$ walked within a day in doctors of different specialties.

\begin{tabular}{|c|c|c|c|c|}
\hline 1 & 2 & 3 & 4 & \\
\hline Gastroenterologists & Cardiologists & Pulmonologists & Physicians & M-U, p \\
\hline $\begin{array}{l}7476 \\
{[4961 \div 10049]}\end{array}$ & $\begin{array}{l}7042 \\
{[3055 \div 10419]}\end{array}$ & $\begin{array}{l}3766 \\
{[2477 \div 5993]}\end{array}$ & $\begin{array}{l}10299 \\
{[6887 \div 10520]}\end{array}$ & $\begin{array}{l}P I-2=0.66 \\
P I-3=0.16 \\
P I-4=0.57 \\
P 2-3=0.35 \\
P 2-4=0.17 \\
P 3-4=0.03\end{array}$ \\
\hline
\end{tabular}

day among all subjects included to the study was 8007 [5742 $\div 10430]$; at the same time, the median of steps walked by men was 8462 [5742 $\div 10430$ ] steps a day, and women walked 7479 [5574 $\div 10999]$ steps. There were no significant difference between doctors in walked steps per day except physicians. The physicians walked significantly more steps per day in comparison with pulmonologists.

To a certain extent, insufficient physical activity is related with the daily use of cars $-27.7 \%$ of the total number of examined subjects uses a car on a daily basis. This percentage was especially high among men $55.5 \%$, and lower among women $-18.5 \%$. At the same time only $22.2 \%$ of the study subjects (all women) keeps up a regular training program.

Evaluation of nutritional behavior of medical doctors demonstrated that the majority of doctors consumed more than $5 \mathrm{~g}$ of sodium chloride a day. Besides, the doctors consumed sweet carbonated drinks more than 3 times a week, despite the fact that almost all of them were aware of the harm of these drinks for the health. Besides, majority of questioned doctors admitted that they do not deliberately exclude trans fats from the diet. Except for gastroenterologists, the doctors quite rarely examined the composition of food products upon their purchase (Table 4).

Thus, the doctors themselves poorly comply with recommendations they give to patients in their daily practice. It should be mentioned that medical doctors are the most aware of the necessity to correct such behavioral risk factors as low physical activity, smoking, and excessive salt consumption. At the same time, our data obtained by the way of examination of Ukrainian doctors are different from the results of survey conducted by Bolbrinker J, et al. The authors revealed a close correlation between awareness of guideline recommendations and their implementation into clinical management. It was shown that European physicians place a stronger emphasis on regular exercise and weight reduction than on the other recommended lifestyle changes [3]. High level of smoking, hypodynamia and intake of unhealthy food were established by Anischenko A, et al. upon examination of students. The study conducted by Kałka $\mathrm{D}$, et al. revealed an insufficient level of awareness of cardiovascular risk factors among Polish medical students [4].

In the examined cohort, $7.8 \%$ were current smokers and $9.8 \%$ of medical doctors had a smoking history. According to the data of a survey conducted among Italian cardiologists, 9.5\% turned out to be current smokers. The majority of cardiologists (93\%) reported a positive attitude toward smoking cessation strategies, $62 \%$ of them thought that cardiologists themselves should treat smoking dependence, though specific tools (70\%) and education for the management of smoking cessation are lacking (66\%) [5].

An interesting fact is that behavioral risk factors were more pronounced in students of medical institutes compared to future teachers and physical activity instructors. Besides, students of medical institutes more frequently showed abdominal obesity signs [6]. Results of a quite big $(n=7228)$ Turkish study showed that in this cohort of mainly middle-aged Turkish doctors, the age-standardized rates of chronic diseases were lower than the rates in the general population except for the rates of hyperlipidemia and coronary artery disease. However, doctors did show quite low rates of receipt of screening practices [7]. It should be mentioned that doctors are more exposed to an additional risk factor - permanent stress. Comparison of stress response of doctors and students has shown that stress exerted more pronounced effect namely on doctors [8].

Our study has demonstrated rather low level of physical activity and domination of unhealthy nutritional habits in doctors. These behavioral peculiarities are associated with excessive body weight, low level of muscular tissue, and high level of fatty tissue. Therapists are exposed to behavioral risk factors most of all. The obtained data dictate the necessity of creation of special doctor-oriented programs on correction of behavioral risk factors.

\section{Summary}

The purpose of this study was to investigate the behavioral risk factors in medical doctors of different specialties. Fifty one doctors of different specialties took part in the study. Body mass index, waist circumference, body composition and physical activity were measured. Body composition was assessed using bioelectric impedance method on an apparatus Omron Body Composition Monitor BF511. Physical activity was assessed by the number of steps walked within a day using a pedometer Omron Walking style III step counter HJ-203-EK. Also, nutrition habits and smoking status were evaluated. The median BMI 
Table 4. Nutritional habits of medical doctors of different specialties.

\begin{tabular}{|c|c|c|c|c|c|}
\hline & $\begin{array}{l}\text { Gastroenterologists } \\
\mathrm{n}=12\end{array}$ & $\begin{array}{l}\text { Cardiologists } \\
\mathrm{n}=14\end{array}$ & $\begin{array}{l}\text { Pulmonologists } \\
\mathrm{n}=9\end{array}$ & $\begin{array}{l}\text { Therapists } \\
\mathrm{n}=16\end{array}$ & $\begin{array}{l}\text { Phi-square } \\
\text { Fisher exact p }\end{array}$ \\
\hline Consumption of more than $5 \mathrm{~g}$ of sodium chloride a day & $8(66.7 \%)$ & $9(64.3 \%)$ & $5(55.5 \%)$ & $14(87.5 \%)$ & $\begin{array}{l}\mathrm{P}_{1-2}=0.61 \\
\mathrm{P}_{1-3}=0.47 \\
\mathrm{P}_{1-4}=0.19 \\
\mathrm{P}_{2-3}=0.50 \\
\mathrm{P}_{2-4}=0.14 \\
\mathrm{P}_{3-4}=0.097\end{array}$ \\
\hline $\begin{array}{l}\text { Awareness of the harm of excessive sodium chloride } \\
\text { consumption }\end{array}$ & $12(100 \%)$ & $14(100 \%)$ & $9(100 \%)$ & $16(100 \%)$ & NA \\
\hline Do not exclude trans fats from the diet & $6(50.0 \%)$ & $9(64.3 \%)$ & $5(55.5 \%)$ & $16(93.7 \%)$ & $\begin{array}{l}\mathrm{P}_{1-2}=0.37 \\
\mathrm{P}_{1-3}=0.58 \\
\mathrm{P}_{1-4}=0.01 \\
\mathrm{P}_{2-3}=0.50 \\
\mathrm{P}_{2-4}=0.059 \\
\mathrm{P}_{3-4}=0.04\end{array}$ \\
\hline $\begin{array}{l}\text { Are aware of the necessity to control the level of consumed } \\
\text { trans fats }\end{array}$ & $12(100 \%)$ & $14(100 \%)$ & $7(77.8 \%)$ & $7(43.7 \%)$ & $\begin{array}{l}\mathrm{P}_{1-3}=0.17 \\
\mathrm{P}_{1-4}=0.002 \\
\mathrm{P}_{2-3}=0.14 \\
\mathrm{P}_{2-4}=0.001 \\
\mathrm{P}_{3-4}=0.11\end{array}$ \\
\hline Read the composition of products at their purchase & $8(66.7 \%)$ & $3(21.4 \%)$ & $1(11.1 \%)$ & $5(31.3 \%)$ & $\begin{array}{l}\mathrm{P}_{1-2}=0.03 \\
\mathrm{P}_{1-3}=0.02 \\
\mathrm{P}_{1-4}=0.07 \\
\mathrm{P}_{2-3}=0.48 \\
\mathrm{P}_{2-4}=0.43 \\
\mathrm{P}_{3-4}=0.27\end{array}$ \\
\hline $\begin{array}{l}\text { Are aware of the necessity to read and evaluate the } \\
\text { components of food products }\end{array}$ & $14(100 \%)$ & $14(100 \%)$ & $8(88.8 \%)$ & $8(50.0 \%)$ & $\begin{array}{l}\mathrm{P}_{1-3}=0.43 \\
\mathrm{P}_{1-4}=0.004 \\
\mathrm{P}_{2-3}=0.39 \\
\mathrm{P}_{2-4}=0.002 \\
\mathrm{P}_{3-4}=0.06\end{array}$ \\
\hline
\end{tabular}

in cardiologists was $29.9 \mathrm{~kg} / \mathrm{m}^{2}$, the same in therapists was $30.1 \mathrm{~kg} / \mathrm{m}^{2}$, $30.0 \mathrm{~kg} / \mathrm{m}^{2}$ in gastroenterologists and $29.2 \mathrm{~kg} / \mathrm{m}^{2}$ in pulmonologists. Four $(7.8 \%)$ of the examined doctors smoked. The median number of steps walked within a day among all subjects included to the study was 8007 [ $5742 \div 10430$ ]; at the same time, the median of steps walked by men was $8462[5742 \div 10430]$ steps a day, and women walked 7479 [5574 $\div 10999]$ steps. The study has demonstrated rather low level of physical activity and domination of unhealthy nutritional habits in doctors. These behavioral peculiarities are associated with excessive body weight, low level of muscular tissue, and high level of fatty tissue. Therapists are exposed to behavioral risk factors most of all. The obtained data dictate the necessity of creation of special doctororiented programs on correction of behavioral risk factors.

\section{References}

1. Li C, Balluz LS, Okoro CA, Strine TW, Lin JM, et al. (2011) Surveillance of certain health behaviors and conditions among states and selected local areas --- Behavioral Risk Factor Surveillance System, United States, 2011. MMWR Surveill Summ 63: $1-149$.

2. Piepoli MF, Hoes AW, Agewall S (2016) European Guidelines on cardiovascular disease prevention in clinical practice: The Sixth Joint Task Force of the European Society of Cardiology and Other Societies on Cardiovascular Disease Prevention in Clinical Practice (constituted by representatives of 10 societies and by invited experts). Eur Heart J 29: 2315-2381.

3. Bolbrinker J, Zaidi Touis L, Gohlke H, Weisser B, Kreutz R (2017) European guidelines on lifestyle changes for management of hypertension: Awareness and implementation of recommendations among German and European physicians. Herz.

4. Kalka D, Domagala Z, Rusiecki L, Gworys B, Koleda P, et al. (2016) Cardiovascular Risk Factors Among Lower Silesian Students of the Faculty of Medicine: Knowledge and Distribution. Adv Clin Exp Med 25: 341-347.

5. Frisinghelli A, Cesana F, Clavario P, Mureddu GF, Temporelli PL, et al. (2015) Italian cardiologists and tobacco smoking. A survey on the prevalence and knowledge of smoking and strategies for smoking cessation in a cohort of Italian cardiologists. G Ital Cardiol (Rome) 16: 426432
6. Anischenko A, Arhangelskaya A, Klenov M, Burdukova E, Ogarev V, et al. (2017) Behavior Risk Factors Among Russian Students. Int Q Community Health Educ 37: 93-98. [Crossref]

7. Unal S, Tanriover MD, Ascioglu S, Demirkazik A, Ertenli I, et al. (2017) Turkish doctors' cohort: healthy despite low screening. Postgrad Med 129: 393-398. [Crossref]

8. Lala AI, Sturzu LM, Picard JP, Druot F, Grama F, et al. (2016) Coping behavior and risk and resilience stress factors in French regional emergency medicine unit workers: a cross-sectional survey. J Med Life 9: 363-368.

Copyright: (C2017 Anna I. This is an open-access article distributed under the terms of the Creative Commons Attribution License, which permits unrestricted use, distribution, and reproduction in any medium, provided the original author and source are credited. 